\title{
Ways of intensification of economic growth and activation of investment activities in order to ensure the economic security of the Russian Federation
}

\author{
Lyudmila Kopteva ${ }^{1, *}$, Irina Romanova ${ }^{1}$, and Angela Mottaeva ${ }^{2,3}$ \\ ${ }^{1}$ Saint-Petrsburg State University of Aerospase Instrumentation, 67, Bolshaya Morskaia str., 190000, \\ Saint-Petersburg, Russia \\ ${ }^{2}$ Moscow State University of Civil Engineering, 26, Yaroslavskoye Shosse, 109377, Moscow, Russia \\ ${ }^{3}$ Moscow Region State University, 10A, Radio str., 105005, Moscow, Russia
}

\begin{abstract}
Macroeconomic dynamics is in the focus of attention of the scientific community due to the fact that it characterizes the key trends in the development of the national economy. The basic indicator in the system of national accounts is the gross domestic product (GDP), which in general form is the aggregate value of all goods and services produced within the national economy. GDP is widely used in the analysis of economic growth trends. Economic growth, creating conditions for it - the most important goal of economic development, both within the framework of ensuring the economic security of the entire national economy and at the level of an individual enterprise. Nowadays, economic development is characterized by an accelerated rate of scientific and technological progress: new technologies and approaches are being created that have higher efficiency. From a microeconomic point of view, the main factors of production are labor, capital and information. Fixed capital investments (buildings, structures, machinery and equipment) are a key instrument for renewing fixed assets. Investment activity is the process of renewing the capital of an enterprise as a result of modernizing its technical and technological base, which ensures its economic security. Investments, along with government spending, are key drivers of economic growth. As a result, we can confidently assert the high importance of investment activities, both throughout the country and at the level of individual economic entities, as well as their economic independence. The paper shows the ways to intensify economic growth and intensify investment activities in order to ensure the economic security of the Russian Federation.
\end{abstract}

\section{Introduction}

The modern world is characterized by opposite trends: on the one hand, the processes of creating a planetary market for goods, services and capital, called globalization, are actively

\footnotetext{
*Corresponding author:lusis63@mail.ru
} 
developing, and on the other hand, the struggle between states for dominance in this market is intensifying. Competition is intensifying not only between individual states, but also between economic integration associations. According to the authors, the use of classical theories of absolute and comparative advantages, proving the benefits from the participation of countries in the international division of labor, does not always contribute to the preservation of the economic security of national economies [1-2].

\section{Problems}

History shows, including recent events - the spread of the COVID-19 pandemic, that each country should have its own reserves for the production of strategic and vital goods and services, even if their cost is relatively higher than in other economies.

An excessive level of openness of the national economy, which can be quantitatively expressed through indicators of export and import quotas, can not only bring benefits, but also create threats to national security and make it vulnerable from the outside world. This is especially true for the food security of the country. It is impossible to foresee all the threats of the external and internal environment. In this regard, the national economic system must be flexible and adaptive and proactively respond to the challenges of the rapidly changing world.

The policy of protectionism implies a reduction in customs duties for goods exported to other countries and an increase in customs duties for imported goods, which contributes to a decrease in their competitiveness in comparison with domestic counterparts. Nowadays, one can also observe the manifestation of cameralistic views in foreign trade between different countries of the world. For example, the sanctions imposed on the Russian economy in 2014 are an open manifestation of unfair competition that constrains economic turnover between countries and Russia. Besides, in recent years, a huge number of regulations of the World Trade Organization, of which Russia became a member in 2012, have been violated.

Supporters of the Keynesian concept have proven that there are market failures that are associated with the presence of unprotected segments of the population, social conditions for the development of the state, which cannot independently function in market conditions. The social policy of states presupposes the availability of free education, health care, childcare, care for disabled people, pensioners, etc.

All these measures of social support require significant financial resources, and the state must find appropriate sources of funding and properly distribute them. Therefore, to ensure economic and social stability, it is necessary to more actively apply state regulation of production, employment and money circulation.

Thus, these views on ensuring national economic security by regulating the internal conditions of macroeconomic growth were actively used until the end of the twentieth century, the governments of many countries of the world were actively distributing government orders and subsidies, and introduced measures of direct administrative control over competition.

\section{Theoretical and methodological foundations}

The concepts of economic growth and economic development, with general similarities, have serious differences. Economic development, in comparison with economic growth, is a more meaningful category. The difference lies in the plane of the quality of life of the population: economic development, in addition to growth in output, is also characterized by the dynamics of the quality of life of the population. 
The goal is to study ways to intensify economic growth and intensify investment activities in order to ensure the economic security of the Russian Federation in modern conditions.

The methodological basis was formed by such methods and techniques of statistical analysis as analysis of dynamics and structure, means of correlation and regression analysis, identifying the main trend and extrapolating the results.

The research information base is presented by official data and materials of the Federal State Statistics Service (Rosstat), the Bank of Russia, the Ministry of Finance, and the World Bank [1-4].

Nowadays, the relevance of statistical methods is not in doubt, since, being very simple to implement, at the same time, they allow getting a clear idea of the effectiveness of investments, especially at the first stage of assessment [5, p. 91].

The key motivational incentives for foreign investors to export capital are:

- the difference in production costs in different countries;

- higher return on capital and lower tax burden.

Foreign direct investment directly affects the development of international economic relations, and at present, almost all countries are both exporters and importers of direct investments.

Terekhova A.N. believes that "in the process of implementing innovative activities that require additional sources of investment, one can refuse to attract financial resources characterized by a high degree of risk, i.e. to avoid it, which will help to completely avoid potential losses associated with unreliable sources of funding, but on the other hand, this does not allow obtaining a positive financial result in the implementation of innovation and investment projects" [6].

The ability of an economy to grow depends on a number of factors that determine the rate and scale of long-term growth in real output, the possibility of improving the efficiency and quality of growth.

According to the method of influencing economic growth, direct and indirect factors are distinguished.

Direct factors include factors that make economic growth realistically possible. This is a group of aggregate supply factors:

- the number and quality of the workforce;

- availability and accessibility of extraction of natural resources;

- accumulated fixed capital in the economy;

- the level of technological and organizational development of production;

- the degree of business development in the country.

Indirect factors of economic growth include such factors of aggregate demand as:

- reducing the degree of monopolization in the economy and strengthening the competitive environment;

- tax burden and climate in the economy;

- the efficiency and effectiveness of the monetary system;

- the level of government, investment and consumer spending;

- growth in net exports;

- quality of the redistribution of production resources;

- an effective system for the redistribution of incomes of the population.

Among the group of indicators that allow assessing the results and nature of the economic development of the national economy, the central indicator is the gross domestic product (GDP).

One of the greatest achievements of the theory of economic growth is the development of the Robert Solow model. Solow built his model taking into account the ideas of both Keynesian and neoclassical theories. From Keynesian theory, Solow borrowed the function 
of investment, the volume of which is made dependent on income and the savings rate.

According to neoclassical theory, it relies on the apparatus of the production function, supplements the factors of economic growth with population growth and technological progress. [7]:

Solow's model is based on a number of prerequisites. Among them, the main ones are

1. The object of modeling is a private closed economy, in which the equilibrium is determined by the formula:

$$
Y=C+I
$$

2. The target function of the model is the growth of the total volume of the product, and the increase in its volume per employee, i.e. the growth of labor productivity.

3. Labor productivity depends on its capital-to-labor ratio. This provision is implemented on the basis of the transformation of the simplest production function:

$$
Y=F(K, L) \text {. }
$$

4. The capital-labor ratio is made dependent on three factors: capital accumulation, population growth, technological progress.

5. Investments are equal to savings.

Therefore,

$$
i=s \cdot y, \text { or } i=s \cdot f(k) \text {. }
$$

On the basis of the above prerequisites, the influence of individual factors on the capital-labor ratio and, as a consequence, on economic growth, i.e. labor productivity, is determined.

The first factor is capital accumulation. According to the model, the amount of capital increases due to investment and decreases due to its depreciation, i.e., amortization. The change in the volume of capital per employee, i.e. the capital-labor ratio, depends on the ratio between investment and depreciation. Of course, the capital-labor ratio also depends on the size of the population. But for now, we abstract from this factor and assume that the number of the population is constant.

The change in the capital-labor ratio, which depends only on investment and depreciation, is determined by the formula:

$$
\Delta k=i-d \cdot k
$$

Since, in accordance with the assumptions of the model, $i=s \cdot f(k)$, the change in the capital-labor ratio can be defined as follows:

$$
\Delta k=s \cdot f(k)-d \cdot k
$$

Depending on what factors cause an increase in production volumes, two forms of economic growth are distinguished: extensive and intensive.

Extensive growth is achieved provided that the volume of production increases only due to an increase in the volume of factors of production with their constant efficiency. This means that economic growth is purely extensive, when the volume of production increases in direct proportion to the increase in the number of factors of production. If, on the contrary, the growth in production occurs only due to an increase in the productivity of production factors, then this means that the economy is growing on a purely intensive basis.

However, it should be noted that there is no purely extensive or purely intensive 
economic growth in the real economy. In fact, the volume of production increases on the basis of a certain combination of extensive and intensive types of economic growth.

Therefore, assessing the real economy, we can talk about its predominantly extensive or predominantly intensive growth.

Economic growth consists in increasing the output of the national economy, i.e. in the growth of the real (cleared of inflation) gross domestic product (GDP).

At the same time, economic theory considers two ways to increase it:

1) as part of closing the recessive gap (bringing aggregate demand to potential GDP);

2) within the framework of the growth of the potential volume of output of goods and services.

Graphically, the interpretation of the two ways of GDP growth can be illustrated using Figures 1 and 2 .

As can be seen from Fig. 1, the first way to increase the volume of production does not affect the production potential of the national economy (potential level of output) in any way. At the same time, it is expressed through the approximation of aggregate demand to the long-term aggregate supply, which characterizes potential GDP: $A S^{L}=\mathrm{Y}_{2}=\mathrm{Y}_{\mathrm{p}}$

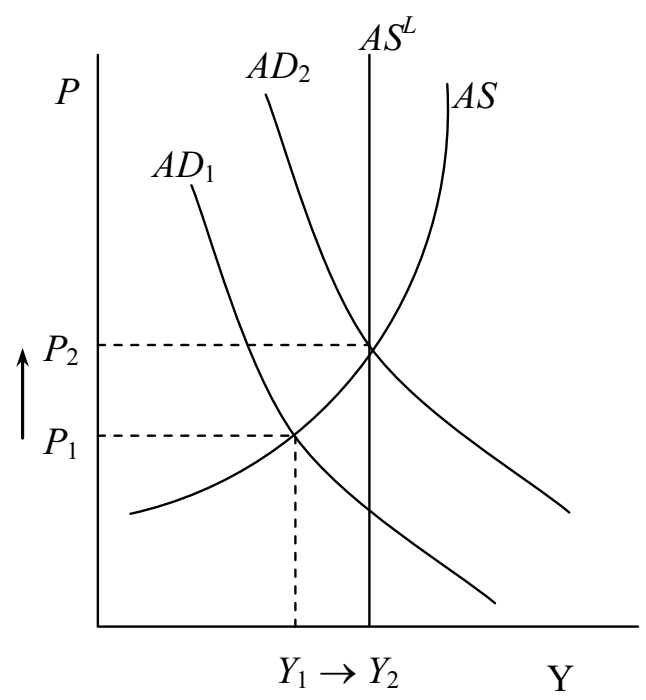

Fig. 1. Growth in real GDP as part of closing the recessive gap.

In this regard, the growth of production in this case is not economic growth, but represents the recovery of the economy to a state characterized by full employment of the labor force. In fig. 2, the growth of GDP volumes from $Y_{1}$ to $Y_{2}$ occurs due to an increase in the level of aggregate demand, and is expressed by the displacement of the aggregate demand curve from $A D_{1}$ to $A D_{2}$.

The second path of economic growth is an increase in potential GDP. The growth of potential GDP indicates an increase in the productive potential of the economy and is accompanied by an increase in the scale of the economy itself.

Fig. 2 shows that output is able to grow from $Y_{1}$ to $Y_{2}$, i.e. in strict accordance with the long-term aggregate supply and the size of potential GDP. This is expressed by moving the long-run aggregate supply curve from $A S_{1}^{L}$ to $A S_{2}^{L}$ (Ivasenko, A.G. Macroeconomics: Textbook / A.G. Ivasenko, Ya. I. Nikonov. - M.: KnoRus, 2016.-280 p.).

An increase in output as a result of an increase in the production potential of the national economy occurs only if the dynamics of aggregate demand corresponds to the dynamics of potential GDP. 


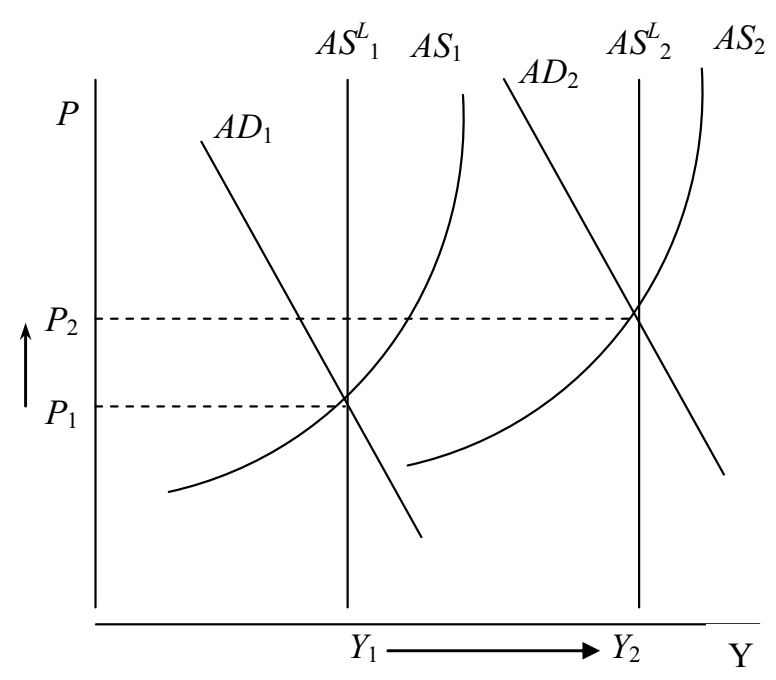

Fig. 2. Real GDP growth on the basis of potential output growth.

Thus, economic growth is expressed in the long-term growth of output volumes due to the growth of the potential level of GDP in conditions when the aggregate demand is characterized by identical dynamics.

\section{Analysis}

Undoubtedly, investment is a critical factor in ensuring economic growth. In addition, the dynamics of investments in fixed assets largely influences the state of economic security of the Russian Federation. That is, for the RF to enter the trajectory of sustainable economic growth in accordance with the goals of economic security, it is necessary to intensify investment processes.

However, the intensification of investment activity lies in the search for sources of financing for the necessary investments. These sources can be either internal or external. Internal sources include own funds of enterprises, bank loans, budget funds and funds of the population. External sources include channels of international capital movement.

Foreign direct investment (FDI) is a form of international capital movement. Unlike portfolio investments, they can be accompanied by the export of technologies, i.e. act as one of the tools for bridging the technological gap between different countries.

The impact of FDI can be controversial. However, the interaction of foreign investors and the recipient country contains potential for possible areas of long-term interest. This necessitates a comprehensive effective government policy on FDI. Such a policy should maximize the benefits associated with attracting foreign capital and minimize negative consequences [8].

FDI flows are primarily characterized by outflows and inflows. The dynamics of the net outflow and inflow of FDI to the Russian Federation is shown in Fig. 3. 


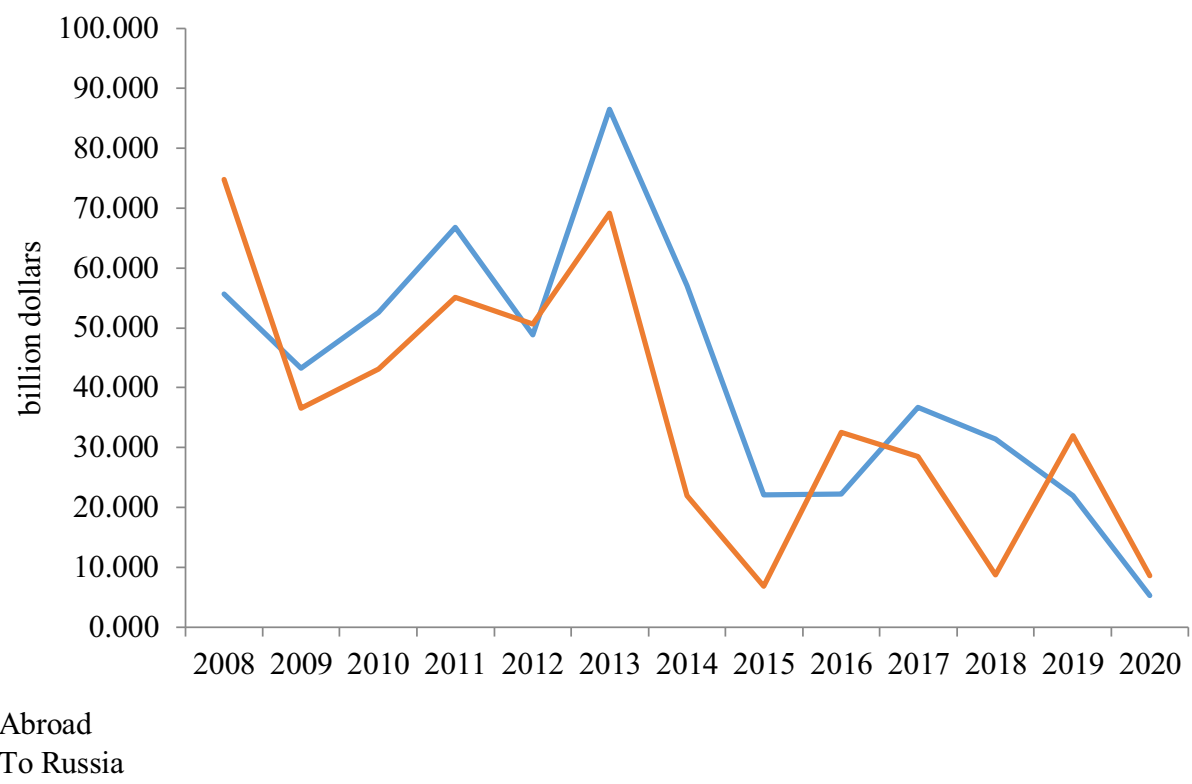

Fig. 3. Dynamics of inflows and outflows of FDI to (from) Russia, billions of dollars. Source: http://www.cbr.ru/vfs/statistics/credit_statistics/direct_investment/21-dir_inv.xlsx.

Total FDI inflows to the Russian Federation for the period 2008 - 2020 amounted to 468.827 billion dollars, which is $74.85 \%$ of the total inflow for the period $1994-2020$. The total outflow of FDI from the Russian Federation for the period $2008-2020$ is 550.576 billion dollars ( $80.45 \%$ of the total outflow).

Table 1 shows the RF FDI balance for the period $1994-2020$.

Table 1. FDI balance of the Russian Federation for the period $1994-2020$, million USD. Source: http://www.cbr.ru/vfs/statistics/credit_statistics/direct_investment/21-dir_inv.xlsx.

\begin{tabular}{|c|c|c|c|c|c|}
\hline Period & $\mathbf{1 9 9 4 - 1 9 9 9}$ & $\mathbf{2 0 0 0}-\mathbf{2 0 0 7}$ & $\mathbf{2 0 0 8} \mathbf{- 2 0 1 4}$ & $\mathbf{2 0 1 5 - 2 0 2 0}$ & Total \\
\hline Abroad & 8399 & 125433 & 410821 & 139754 & 684407 \\
\hline To Russia & 16247 & 141307 & 351455 & 117371 & 626380 \\
\hline FDI balance & 7848 & 15875 & -59366 & -22383 & -58026 \\
\hline
\end{tabular}

As a result, if prior to 2008, the Russian Federation acted as a recipient of FDI (the positive balance of FDI for the period 1994 - 2008 is 23.723 billion dollars), then from 2008 to 2020, the excess of outflow of FDI over their inflow (negative balance of 81.749 billion dollars) allows concluding that the Russian Federation has turned into a donor of foreign direct investment.

As for geography, for the period $2007-2019$ and for three quarters of 2020, the total volume of FDI in the Russian Federation amounted to 519.425 billion dollars. Cyprus is the leader in foreign direct investment, the share of this state in the total inflow of FDI is $10.60 \%$ (Table 2).

Table 2. Geographic structure of FDI in the Russian Federation (2007 - 2020). Source: http://www.cbr.ru/vfs/statistics/credit_statistics/inv_in-country.xlsx.

\begin{tabular}{|c|c|}
\hline Country & The share of incoming FDI, in \% \\
\hline Cyprus & $10.60 \%$ \\
\hline Netherlands & $9.67 \%$ \\
\hline Great Britain & $7.71 \%$ \\
\hline Virgin Islands & $7.07 \%$ \\
\hline
\end{tabular}




\begin{tabular}{|c|c|}
\hline Bahamas & $6.47 \%$ \\
\hline Ireland & $5.49 \%$ \\
\hline Luxembourg & $5.46 \%$ \\
\hline Bermuda & $4.53 \%$ \\
\hline France & $3.73 \%$ \\
\hline Germany & $3.28 \%$ \\
\hline Switzerland & $2.16 \%$ \\
\hline Austria & $1.80 \%$ \\
\hline USA & $1.63 \%$ \\
\hline Sweden & $1.24 \%$ \\
\hline Jersey & $1.23 \%$ \\
\hline Hong Kong & $1.18 \%$ \\
\hline PRC & $0.81 \%$ \\
\hline Gibraltar & $0.77 \%$ \\
\hline Hungary & $0.73 \%$ \\
\hline Japan & $0.73 \%$ \\
\hline Other countries & $23.71 \%$ \\
\hline
\end{tabular}

The Netherlands is on the second place $(967 \%)$, the UK is on the third $(7.71 \%)$. It is followed by the Virgin Islands (7.07\%), the Bahamas (6.47\%), Ireland $(5.49 \%)$, Luxembourg $(5.46 \%)$, Bermuda (4.53\%), France $(3.73 \%)$, and Germany closes the top 10 with a share of $3.28 \%$. In total, $64.02 \%$ of the total inflow of $\$ 519.425$ billion was directed from these countries. As a result, it can be concluded that mainly FDI in the Russian Federation "comes" from offshore jurisdictions.

Attracting foreign capital to Russia is an important strategic advantage for the development of the Russian economy. Russia views foreign investment as an economic factor influencing: 1) the acceleration of economic and technological progress; 2) renovation and improvement of manufacturing enterprises; 3) control of modern production management methods. In 2018, Russia was ranked 9th among the twenty most attractive countries with foreign investment in the annual report by Ernst\&Young. In 2017, foreign investors invested in 211 projects in the Russian Federation, which is $11 \%$ less than in the previous year (238 projects) [9].

An analysis of foreign direct investment from Russia shows that capital is exported to the same offshore zones. This indicates that investments in Russia represent a return of previously withdrawn capital and are carried out mainly by organizations of Russian origin. This phenomenon is called cyclicality ("capital cycle"). It is possible to save capital in the country if we purposefully and actively improve the investment climate. An increase in the position of Russia in the World Bank's DoingBusiness rating theoretically indicates an improvement in the investment climate [10]. However, the results of the rating are not noticed by investors, who persistently say that the main obstacle to modernization and expansion of foreign investment is the lack of normally functioning institutions, administrative pressure on business, low labor standards, a wide shadow labor market and constant changes in the field of regulation [11]. By adopting Federal Law No. 140-FZ of 06/08/2015 "On the Voluntary Declaration of Property and Bank Accounts (Deposits) of Individuals" [12], which provides for an amnesty for capital exported abroad, the country's leadership seeks not only to return capital, but also to stop its escape.

The rating of countries investing in the Russian economy has undergone significant changes compared to 2017. Despite the difficult period in relations with Russia, the United States of America for the first time since 2013 leads this rating in terms of the number of investment projects in 2018, which is by $74 \%$ (33 projects) more than in 2017 (19 projects). Germany is in second place, where investments in the economy of the Russian Federation decreased by $14 \%$ ( 24 projects) compared to 2017 (28 projects). In 2018, there was a decrease in the number of investments from China - the first in the list of investors in the 
Russian economy moved to third place [13].

Let us analyze FDI from the RF in a similar way (Table 3).

Table 3. Geographic structure of FDI from the Russian Federation (2007 - 2020). Source: http://www.cbr.ru/vfs/statistics/credit_statistics/direct_investment/18-dir_inv.xls.

\begin{tabular}{|c|c|}
\hline Country & The share of outcoming FDI, in \% \\
\hline Cyprus & $33.34 \%$ \\
\hline British Virgin Islands & $15.48 \%$ \\
\hline Netherlands & $4.96 \%$ \\
\hline Switzerland & $4.05 \%$ \\
\hline Great Britain & $3.79 \%$ \\
\hline Austria & $3.07 \%$ \\
\hline USA & $2.83 \%$ \\
\hline Germany & $2.74 \%$ \\
\hline Luxembourg & $2.43 \%$ \\
\hline Singapore & $2.28 \%$ \\
\hline Bermuda & $1.95 \%$ \\
\hline Turkey & $1.85 \%$ \\
\hline Bahamas & $1.33 \%$ \\
\hline Ireland & $1.31 \%$ \\
\hline Spain & $1.24 \%$ \\
\hline Jersey & $1.11 \%$ \\
\hline Gibraltar & $0.97 \%$ \\
\hline France & $0.84 \%$ \\
\hline Bulgaria & $0.62 \%$ \\
\hline Italy & $0.58 \%$ \\
\hline Other countries & $13.24 \%$ \\
\hline
\end{tabular}

Total FDI from the Russian Federation for 2007 - 2020 amounted to 591.056 billion dollars. One third of them was directed to Cyprus, $15.48 \%$ - to the Virgin Islands, $4.96 \%$ to the Netherlands, $4.05 \%$ to Switzerland, and 3.79\% to Great Britain. In total, the listed top 5 recipient countries account for $61.62 \%$ of total Russian direct investment. Comparative analysis according to tables 1 and 2 allows concluding that the movement of FDI is mostly associated with offshore zones of the global economy. In other words, Russian capital is more focused on minimizing tax deductions, which is explained by such cooperation with offshore companies.

As reasons for the decline in global FDI, a report on global investment by the United Nations Conference on Trade and Development (UNCTAD) named "uncertainty caused by a weakening macroeconomic environment and a number of perceived risk factors, including those associated with the euro area crisis" [14].

As the analysis has shown, the dynamics of the FDI balance in the Russian economy is negative, i.e. the Russian Federation is a donor country in the international movement of capital. In the context of tougher anti-Russian sanctions, the use of external sources becomes much more difficult. In this regard, in order to ensure financing of upcoming investments, it is necessary, first of all, to pay attention to internal sources.

Bank loans at a certain stage are able to give impetus to the economic development of the Russian Federation. However, the main problem lies in the plane of the cost of credit resources. Bank loans are the main source of financing for small and medium-sized businesses. However, if you look at fig. 4, you can see that the return on assets of Russian enterprises in 2013 was $4.5 \%$, in $2014-2.5 \%$, in $2015-3.7 \%$, in $2016-5.9 \%$, in 2017 $3.8 \%$, in $2018-4.7 \%$, in $2019-6.8 \%$, and in $2020-4.5 \%$. 


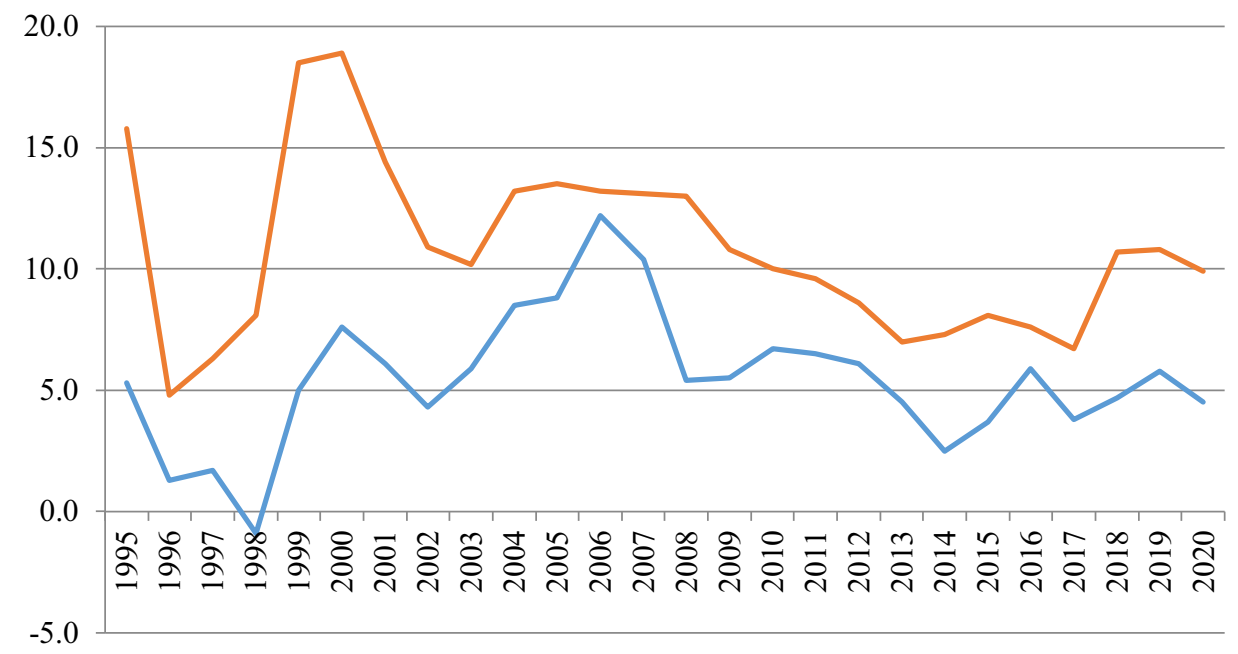

- Profitability of sold goods, products,

- Return on assets

Fig. 4. The profitability of Russian business, in \%. Source:

https://rosstat.gov.ru/storage/mediabank/4zDA2Fwl/dinrent.xls.

As a result of comparing the return on assets, and this is the main indicator of the efficiency of the operation of investments, with the dynamics of the key rate (and this is a benchmark for the cost of credit resources), it is possible to reach a fundamental problem the excess of interest rates on loans over profitability. As a result, a mechanism is being created for the expanded reproduction of bankruptcy of those Russian enterprises whose property is predominantly financed by bank loans.

At the same time, it is worth noting the fact that during 2020 the Bank of Russia reduced the key rate from $6.25 \%$ to $4.25 \%$. And this, nevertheless, instills optimism that the Bank of Russia, in addition to its inflation target, is able to achieve its goals for sustainable economic growth. Nevertheless, the use of credit resources for a large-scale intensification of investment activity is possible only with the transition of the Central Bank to a more independent policy, the creation of a pool of investment banks aimed primarily at lending to the real sector of the economy. Moreover, this lending should be long-term and at a minimum interest.

Budget investments, as we have already found out, dominate among the attracted sources of investment financing. At the same time, as we have also found out, in 2020, the federal budget was executed with a record deficit. In such conditions, budgetary investments from the federal budget also cannot act as a source of funding. However, in Russia, there is a National Welfare Fund (NWF) - a sovereign reserve fund that accumulates super profits from the sale of hydrocarbons (Fig. 5). 


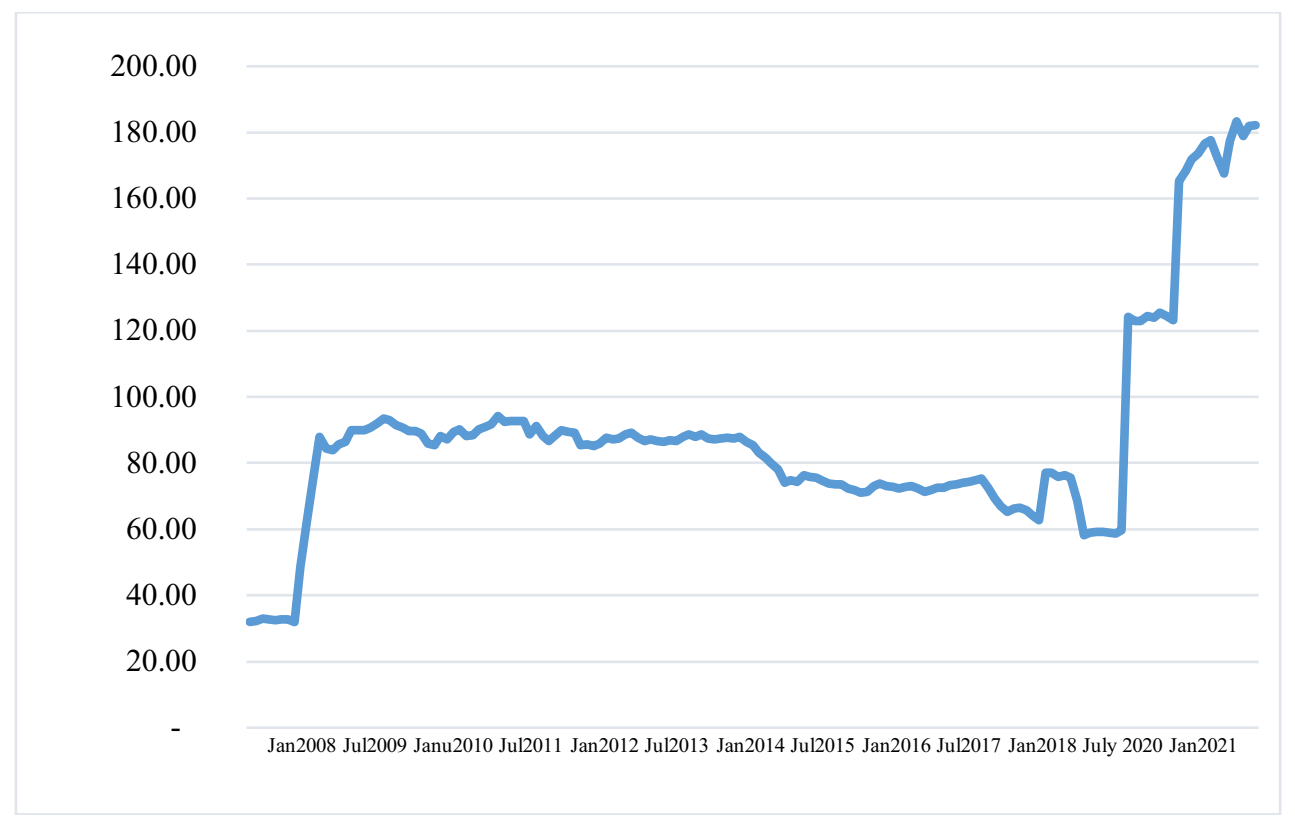

Fig. 5. Dynamics of NWF funds from January 2008 to March 2020, billion dollars. Source: https://minfin.gov.ru/common/upload/library/2021/04/main/01.04.2021.xlsx.

As of 01.04.2021, the NWF has accumulated 13.8 trillion rubles, which is equivalent to 182.32 billion US dollars. In relation to GDP, this is $11.9 \%$.

Nowadays, in the scientific community, there are heated discussions about the need to use the funds of the NWF for the development of the Russian economy. In the context of the crisis, the absence of an external inflow of real FDI, and not reinvested from offshore, previously withdrawn to them funds, the use of NWF funds is distinguished by a certain temptation.

As part of our research, by means of fairly simple calculations, we will assess how effective the use of the funds of the NWF will be, provided they are invested in fixed assets

To determine the effects, it is necessary to:

1. Determine the parameters and statistical significance of the regression "Investment in fixed assets - GDP";

2. Determine the parameters and statistical significance of the regression "GDP - federal budget revenues".

Having two functions, we will be able to calculate the effect of investing NWF funds: first, determine the GDP growth due to investment growth, and then the increase in federal budget revenues from GDP growth. Comparing the generated income with the initial investment will give us an idea of the effect. In this case, the level of significance is taken at the level $\alpha=0.0005$, i.e. the statistical reliability of the models should be $99.95 \%$.

To construct a linear function of the dependence of GDP on the dynamics of investments in fixed assets, we will use the already familiar apparatus of correlationregression analysis.

Let us introduce the notation:

$x$ - investments in fixed assets, trillion rub.;

$\mathrm{y}$ - nominal GDP, trillion rub.

To identify the nature of the dependence, we will construct a scatter diagram (correlation field), simultaneously reflecting on it the regression equation and the coefficient of determination (Fig. 6). 


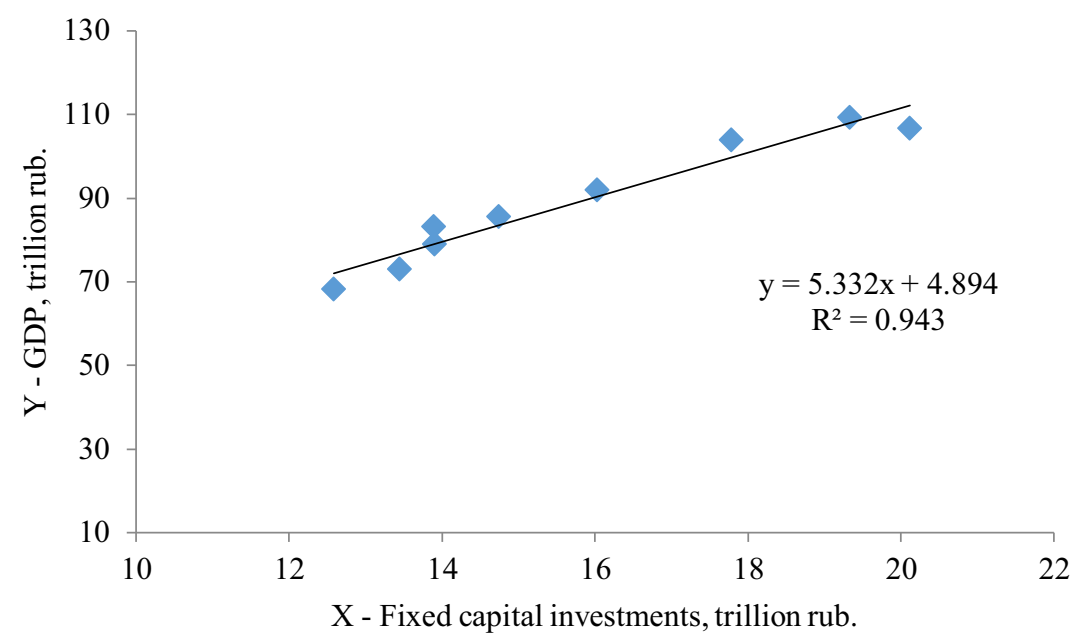

Fig. 6. Relationship between investment and economic growth (data from 2012 to 2020)

The required equation will have the following form:

$$
y=4.894+5.332 x
$$

$F$-statistics:

$$
F_{\text {obs }}=\frac{(n-m) R^{2}}{(m-1)\left(1-R^{2}\right)}=\frac{(9-2) 0.943}{(2-1)(1-0.943)}=115.8
$$

Critical value:

$$
F_{c r}=F(0.9995 ; 1 ; 7)=36.988
$$

Since, $F>F_{c r}$, then the model describing the dependence of GDP in current prices on the dynamics of investment in fixed assets is statistically significant with a probability of 0.9995 . The statistical reliability of the obtained equation is higher than the predetermined value of $99.95 \%$. In other words, we can conclude that investments in fixed assets are a key factor in economic growth in the Russian economy. Consequently, the intensification of investment activity is seen as a necessary condition for the Russian Federation to enter the trajectory of sustainable economic growth.

Similarly, we will find the dependence of federal budget revenues on the dynamics of GDP (Fig. 7). 


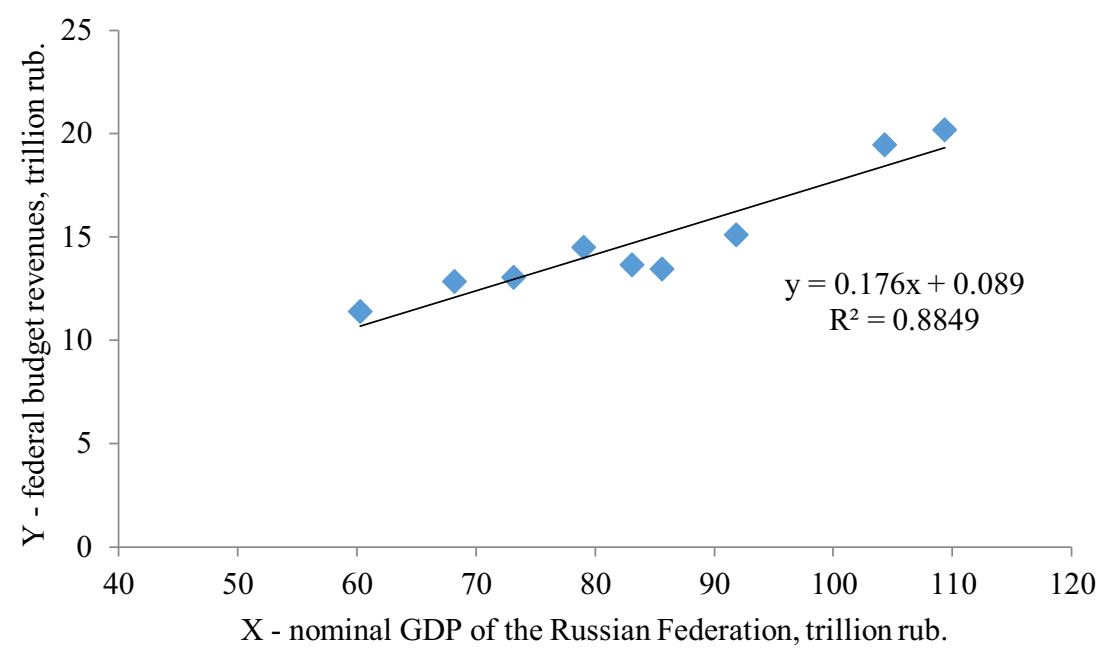

Fig. 7. Correlation "GDP - federal budget revenues".

We obtain the following equation of the influence of GDP dynamics on the level of federal budget revenues:

$$
y=0.089+0.176 x
$$

$F$-statistics:

$$
F_{\mathrm{obs}}=\frac{(n-m)}{(m-1)} \cdot \frac{R^{2}}{1-R^{2}}=7 \cdot \frac{0.8849}{1-0.8849}=61.481
$$

Critical F-statistics:

$$
F_{c r}=F(0.9995 ; 1 ; 7)=36.988
$$

Since, $F>F_{c r}$, then the dependence of federal budget revenues on the nominal GDP of the Russian Federation obtained in the course of the study is recognized as significant with a probability of $99.95 \%$. That is, the hypothesis is accepted: the growth of the Russian economy leads to an increase in the revenue side of the federal budget. The statistical reliability of the obtained equation is higher than the predetermined value of $99.95 \%$.

As a result, we get two equations:

1) "Federal budget revenues - GDP": $y=0.089+0.176 x$;

2) "GDP - investment": $y=4.894+5.332 x$

Let's say that 1 trillion rubles (investments in fixed assets) is sent from the National Welfare Fund (NWF) to the economy of the Russian Federation. As a result, GDP will grow by 5.332 trillion rubles, federal budget revenues will grow by $0.176 * 5.332=0.94$ trillion rubles. As a result, in order to get to zero, it is required to invest in projects with a yield higher than the national average by $6 \%$.

\section{Corollary}

It can be concluded that in the context of aggravated relations between Russia and the West, it is necessary to intensify cooperation with the BRICS countries, which can become 
a factor that not only compensates for losses in other markets, but also help to stimulate economic growth through the development of interstate cooperation, become a lever increasing Russia's competitiveness in the global economy by using existing competitive advantages and introducing new ones. Russia has a huge investment potential, which, unfortunately, is underutilized. Thus, with a sufficiently balanced approach, a certain part of the NWF can be invested in the Russian economy, which will give it an impetus for development. In turn, economic growth will already provide an increase in federal budget revenues. Note that our calculation, despite the very high statistical significance of the equations obtained, is very primitive and cannot claim absolute accuracy, but can be an argument for the need to intensify the investment activity of the NWF.

\section{Conclusions}

Based on the study, the following conclusions can be drawn.

1. Neo-Keynesian theories of economic growth, as well as neoclassical ones, consider the activation of investment activity as a key factor of economic growth. Investments allow enterprises to modernize their technical and technological base, thereby increasing their own competitiveness and the competitiveness of the entire national economy. Investments make it possible to improve the quality of human capital, finance the introduction of innovative solutions in production and management.

2. The analysis carried out for the period 2008 - 2020 fixes that the decline in investments in fixed assets of the Russian economy is observed only in 2009 and 2015. In 2009 , investments in fixed assets fell by $9.17 \%$, in 2015 - by $0.04 \%$. Except for the abovementioned years, there is an increase in investment for the entire study period $2008-2020$. The largest contribution to the dynamics of investments in fixed assets falls on the period 2010 - 2012: during the recovery 2010 , investments increased by $14.75 \%$ compared to 2009 , having won back not only the fall in 2009, but also exceeded the level of 2008 (by $4.22 \%$ ). In 2011, investments increased by $20.58 \%$, and this is the maximum growth for the entire period from 2008 to 2020. In 2012, the increase in investments slightly decreased, nevertheless, reaching a rather impressive $14.05 \%$. In the subsequent period, the dynamics of investments only once, in 2018, was characterized by a double-digit growth rate (+ $10.95 \%$ ). Thus, we can conclude that there is a growing but dying trend in the dynamics of investments in fixed assets in the economy of the Russian Federation.

3. In the period $2008-2014$, attracted funds dominated in the structure of sources of financing for investments in fixed assets: in 2008, their share in the total amount of investments was $60.5 \%$, and in $2014-54.3 \%$. The peak of the share of borrowed funds is in $2009-62.9 \%$. In 2015, the prevailing source of financing was the own funds of economic entities $(50.2 \%$ versus $49.8 \%)$. In 2020 , the share of borrowed funds amounted to $53.3 \%$, and own funds $-56.7 \%$. That is, quite significant changes in the structure are recorded for the period $2008-2020$. The existing downward trend in the role of borrowed capital in investment financing indirectly indicates an increase in the financial stability of Russian companies and enterprises. At the same time, in the structure of attracted funds, the largest share is characterized by budget investments. In 2008, investments from the budgetary system of the Russian Federation accounted for $34.55 \%$ of all investments financed from borrowed funds. The share of bank loans was $19.50 \%, 10.25 \%$ was financed by borrowed funds from other organizations. In 2020, the share of budget investments increased to $43.19 \%$, bank loans - up to $21.94 \%$.

4. Total FDI inflows to the Russian Federation for the period 2008 - 2020 amounted to 468.827 billion dollars, which is $74.85 \%$ of the total inflow for the period $1994-2020$. The total outflow of FDI from the Russian Federation for the period 2008 - 2020 is 550.576 billion dollars $(80.45 \%$ of the total outflow). As a result, if prior to 2008 the Russian 
Federation acted as a recipient of FDI (the positive balance of FDI for the period 1994-2008 is 23.723 billion dollars), then from 2008 to 2020, the excess of outflow of FDI over their inflow (negative balance of 81.749 billion dollars) allows concluding that the Russian Federation has turned into a donor of foreign direct investment. As for geography, for the period 2007 - 2019 and for three quarters of 2020, the total volume of FDI in the Russian Federation amounted to 519.425 billion dollars. Cyprus is the leader in foreign direct investment, the share of this country in the total inflow of FDI is $10.60 \%$. The Netherlands is on the second place (967\%), the UK is on the third $(7.71 \%)$. It is followed by the Virgin Islands (7.07\%), the Bahamas (6.47\%), Ireland (5.49\%), Luxembourg (5.46\%), Bermuda $(4.53 \%)$, France $(3.73 \%)$, and Germany closes the top 10 with a share of $3.28 \%$. In total, $64.02 \%$ of the total inflow of $\$ 519.425$ billion was directed from these countries. As a result, it can be concluded that mainly FDI "comes" in the Russian Federation from offshore jurisdictions. Total FDI from the Russian Federation for the period 2007 - 2020 amounted to 591.056 billion dollars. One third of them was directed to Cyprus, $15.48 \%$ - to the Virgin Islands, $4.96 \%$ - to the Netherlands, $4.05 \%$ to Switzerland, and 3.79\% to Great Britain. In total, the listed top 5 recipient countries account for $61.62 \%$ of total Russian direct investment. Comparative analysis according to tables 1 and 2 allows concluding that the movement of FDI is mostly associated with offshore zones of the global economy. In other words, Russian capital is more focused on minimizing tax deductions, which is explained by such cooperation with offshore companies.

5. The analysis of macroeconomic dynamics recorded that the decline in the gross domestic product generated by the Russian economy was observed only in 2009 and 2020 . In 2009 , GDP in current prices dropped by $5.98 \%$, in 2020 - by $2.08 \%$. Except for the above-mentioned years, there is an increase in nominal GDP for the entire study period 2008 - 2020. The largest contribution to the dynamics of GDP falls on the period 2010 2012: during the restorative 2010 , GDP grew by $19.33 \%$ in comparison with 2009 , having won back not only the fall in 2009, but also exceeded the level of 2008 (by $12.19 \%$ ). In 2011 , the Russian GDP grew by $20.86 \%$, and this is the maximum growth for the entire period 2008 - 2020. In 2012, the GDP growth slightly decreased, nevertheless, it was quite impressive $13.29 \%$. In the subsequent period, the dynamics of GDP only once, in 2018, was characterized by a double-digit growth rate $(+13.09 \%)$. Thus, we can conclude that there is a growing but dying trend in the dynamics of economic growth in the Russian Federation.

6. If we compare the dynamics of GDP with the dynamics of investments in fixed assets, then the conclusion can be made about a high degree of their symmetry, which indirectly suggests that the dynamics of investments somehow determines the dynamics of GDP. The real GDP of the Russian Federation had a decline in 2009 (-7.82\%), in 2015 ($1.97 \%$ ), and in 2020 - by $2.95 \%$. The reason for the fall in 2009 is the consequences of the impact of the large-scale global economic crisis. The reasons for the decline in the physical volume index in 2015 are seen as sectoral sanctions against the Russian economy imposed by the Western coalition after the reunification of the Crimea with the Russian Federation. The shrinkage of the economy in 2020 was dictated by the negative shock from the spread of the new coronavirus infection. In general, we can conclude that the economy of the Russian Federation is developing quite confidently, although the physical expansion of the economy leaves much to be desired. At the same time, the entry of the world economy into the global crisis provoked both by the action of the global pandemic and by the systemic crisis of the modern development model based on credit expansion and, as a consequence, the growth of the national debt causes a slowdown in the development of the entire global economy.

7. Modeling according to the Solow model records that in the period $2012-2017$, in comparison with 1990 - 2001, there is a decrease in the average annual investment rate, an increase in the retirement rate, and a decrease in the capital-labor ratio. At the same time, 
labor productivity has grown, and the growth rate of the labor force has entered a positive area. That is, at the present stage, both an increase in the labor force and an increase in the efficiency of its use are recorded. The main problem is the decrease in investment activity and the acceleration of the disposal of fixed assets. In this regard, the activation of the investment component of economic growth is seen as a key factor in entering a stable trajectory for the expansion of the Russian economy. At the same time, it is necessary to ensure the achievement of a positive effect both from the quantitative side - the growth of investments in fixed assets, and qualitative side - the increase in capital productivity of the advanced capital.

8. The Russian economy is characterized by the obsolescence of fixed assets. Depreciation of assets in the period 2008 - 2018 consistently exceeded $45 \%$, which undoubtedly affected the competitiveness of the Russian economy. In 2019, the situation was reversed - the depreciation of funds fell to $37.8 \%$. At the end of 2020 , the depreciation of funds reached $38 \%$. At the end of 2020 , the depreciation of agricultural assets is $40.5 \%$, in the mining sector $-55.9 \%$, in manufacturing $-51.5 \%$, in the construction sector $-48.2 \%$, in the transport and logistics complex - 53.9\%, in the field of information and communication $-61.3 \%$, in the field of education $-48.3 \%$, in the field of health and social services $-52.9 \%$.

9. The intensification of investment activity lies in the search for sources of financing for the necessary investments. As we already know from theory, these sources can be either internal or external. Internal sources include own funds of enterprises, bank loans, budget funds and funds of the population. External sources include channels of international capital movement. As the analysis in the second chapter showed, the dynamics of the FDI balance in the Russian economy is negative, i.e. the Russian Federation is a donor country in the international movement of capital. In the context of tougher anti-Russian sanctions, the use of external sources becomes much more difficult. In this regard, in order to ensure financing of upcoming investments, it is necessary, first of all, to pay attention to internal sources. Budget investments, as we have already found out, dominate among the attracted sources of investment financing. At the same time, as we have also found out, in 2020, the federal budget was executed with a record deficit. In such conditions, budgetary investments from the federal budget also cannot act as a source of funding. However, Russia has a National Welfare Fund (NWF) - a sovereign reserve fund that accumulates super profits from the sale of hydrocarbons.

10. As of 01.04.2021, the NWF has accumulated 13.8 trillion rubles, which is equivalent to 182.32 billion US dollars. In relation to GDP, this is $11.9 \%$.

Based on the above, we can conclude that with a sufficiently balanced approach, a certain part of the NWF can be invested in the Russian economy, which will give it an impetus for development. In turn, economic growth will already provide an increase in federal budget revenues. Note that our calculation, despite the very high statistical significance of the obtained equations $(99.95 \%)$, is very primitive and cannot claim absolute accuracy, but can be an argument for the need to intensify the investment activity of the NWF.

The Russian economy definitely needs deep modernization, diversification, and strengthening of the competitiveness of the manufacturing sector. However, like any such large-scale transformation, first of all, it needs large-scale investments. Investments are not only a determining factor in ensuring economic growth, but also in neutralizing key threats to the economic security of the Russian Federation. 


\section{Reference}

1. Federal State Statistics Service, http://www.rosstat.gov.ru/

2. Bank of Russia, http://www.cbr.ru/

3. Ministry of Finance, http://www.minfin.gov.ru/

4. World Bank database, https://data.worldbank.org

5. L.J. Gitman, M.D. Joehnk, Fundamentals of investing (Pearson, London, 2004)

6. A.N. Terekhova, Modern scientific research and innovations 10 (2016) https://web.snauka.ru/issues/2016/10/72269

7. V.V. Kapustina, E.V. Buntova, Scientific community of students: Interdisciplinary research: collection of proceedings of XXXV int. stud. Scientific and practical conf. 24(35) (2021) https://sibac.info/archive/meghdis/24(35).pdf

8. E.P. Ikonnikova, A.A. Mareeva, Problems of the modern economy: materials of the VII Intern. scientific. conf. (Kazan, Young Scientist, 2018) https://moluch.ru/conf/econ/archive/294/13839 /

9. N.S. Akhmadzoda, Vestnik of the Russian New University. Series: Man and Society 1, 24-32 (2021)

10. Doing Business 2015: Going Beyond Efficiency (Washington, World Bank) http://www.worldbank.org/eca/russian/

11. A. Radzivil, Y. Vazyakova, Improving the business climate in Russia (OECD Economic Department, 2015) http://www.oecdru.org/news.html

12. Federal Law of the Russian Federation of June 8, 2015 No. 140-FZ, Rossiyskaya Gazeta. Federal issue No. 6695. 2015.10 June

13. Investment priorities of the "Celestial Empire" (Chamber of Commerce and Industry of the Russian Federation) https://tpprf.ru/ru/interaction/ experts/comments/345697/

14. World Investment Report 2015 (United Nations Conference on Trade and Development) http://www.unctad.org

15. Decree of the President of the Russian Federation of 13.05.2017 N 208, http://www.consultant.ru/document/cons_doc_LAW_216629/ 